\title{
Protective effect of 1,2,4-benzenetriol on LPS-induced NO production by BV2 microglial cells
}

\author{
Rolis Chien-Wei Hou ${ }^{1}$, Yuh-Shuen Chen ${ }^{2}$, Chia-Hsin Chen ${ }^{1}$, Yi-Hsin Chen ${ }^{3}$ \\ \& Kee-Ching G. Jeng ${ }^{3, *}$ \\ ${ }^{1}$ Jen-Teh Junior College of Medical and Nursing Management, Miaoli, Taiwan; ${ }^{2}$ Department of Food \\ Nutrition, Hungkuang University, Taichung, Taiwan; ${ }^{3}$ Department of Education and Research, Taichung \\ Veterans General Hospital, Taichung, Taiwan
}

Received 9 June 2005; accepted 20 September 2005

(C) 2005 National Science Council, Taipei

Key words: brain ischemia, BV-2 cells, inducible nitric oxide synthase, NF- $\kappa \mathrm{B}, \mathrm{p} 38$ MAPK, reactive oxygen species

\section{Summary}

Hydroxyhydroquinone or 1,2,4-benzenetriol (BT) detected in the beverages has a structure that coincides with the water-soluble form of a sesame lignan, sesamol. We previously showed that sesame antioxidants had neuroprotective abilities due to their antioxidant properties and/or inducible nitric oxide synthase (iNOS) inhibition. However, studies show that BT can induce DNA damage through the generation of reactive oxygen species (ROS). Therefore, we were interested to investigate the neuroprotective effect of BT in vitro and in vivo. The results showed that instead of enhancing free radical generation, BT dosedependently $(10-100 \mu \mathrm{M})$ attenuated nitrite production, iNOS mRNA and protein expression in lipopolysaccharide (LPS)-stimulated murine BV-2 microglia. BT significantly reduced LPS-induced NF- $\kappa$ B and p38 MAPK activation. It also significantly reduced the generation of $\mathrm{ROS}$ in $\mathrm{H}_{2} \mathrm{O}_{2}$-induced BV-2 cells and in $\mathrm{H}_{2} \mathrm{O}_{2}$-cellfree conditions. The neuroprotective effect of $\mathrm{BT}$ was further demonstrated in the focal cerebral ischemia model of Sprague-Dawley rat. Taken together, the inhibition of LPS-induced nitrite production might be due to the suppression of NF- $\kappa \mathrm{B}, \mathrm{p} 38$ MAPK signal pathway and the ROS scavenging effect. These effects might help to protect neurons from the ischemic injury.

\section{Introduction}

Previous studies show that neuroprotective abilities of sesame antioxidants are related to their antioxidant properties and/or nitric oxide (NO) inhibition $[1,2]$. Interestingly, hydroxyhydroquinone or 1,2,4-benzenetriol (BT) detected in the instant coffee [3] has a structure that coincides with the water-soluble form of a sesame lignan, sesamol (Figure 1). BT has been known as one of benzene metabolites for years [4]. The urinary concentra-

*To whom correspondence should be addressed. Fax: + 886-42359-2705; E-mail: kcjengmr@vghtc.gov.tw tion of BT is increased linearly to the intensity of exposure to benzene in both men and women [5, 6]. Surprisingly, coffee drinking increases urinary hydrogen peroxide $\left(\mathrm{H}_{2} \mathrm{O}_{2}\right)$ levels which are derived mainly from $\mathrm{BT}$ excreted in urine $[7,8]$.

BT and other benzene metabolites, such as hydroquinone (HQ), benzoquinone (BQ), catechol, can induce DNA damage through the generation of reactive oxygen species (ROS). BT generates $\mathrm{H}_{2} \mathrm{O}_{2}$, which is the dominant active species, and $\mathrm{O}_{2}^{--}$and $\mathrm{OH}$, which plays subordinate roles [9]. However, polyphenols from beverages, green tea, black tea, and coffee also generate $\mathrm{H}_{2} \mathrm{O}_{2}$ in vitro [10]. ROS can damage DNA, RNA, and proteins in 
<smiles>Oc1ccc2c(c1)OCO2</smiles><smiles>Oc1ccc(O)c(O)c1</smiles>

Sesamol Hydroxyhydroquinone, water-soluble form of sesamol

Figure 1. Chemical structures of sesamol and 1,2,4-benzenetriol (BT).

cells and contribute to the pathobiology of many diseases including neurodegeneration and brain ischemia $[11,12]$.

Chronic administration of $\mathrm{HQ}, \mathrm{BQ}$ or $\mathrm{BT}$ to rats for 6 weeks significantly decreases red blood cells and bone marrow cell counts and changes organ weights. In addition, BQ and BT elicit histological injuries in liver, thymus, spleen, kidney and peripheral lymph nodes [13]. Treatment of mice with benzene $(800 \mathrm{mg} / \mathrm{kg})$, or HQ $(100 \mathrm{mg} /$ $\mathrm{kg})$, BT $(25 \mathrm{mg} / \mathrm{kg})$, or BQ $(2 \mathrm{mg} / \mathrm{kg})$ for 3 days, at doses that impair hematopoiesis, sensitize bone marrow leukocytes to produce increased amounts of NO in response to lipopolysaccharides (LPS) and interferon- $\gamma($ IFN- $\gamma)$ [14]. They also increase the sensitivity of the cells to both granulocytemacrophage colony-stimulating factor (GM-CSF) and macrophage colony-stimulating factor (M$\mathrm{CSF}$ ) in the enhancement of NO production [14]. $\mathrm{NO}$ and inflammatory mediators, such as tumor necrosis factor- $\alpha(\mathrm{TNF}-\alpha)$ released from LPSactivated microglia can damage dopaminergic neurons [15]. The long-term supplementation of BT $(1.2 \%, w / w)$ increases mouse lipid peroxidation and type IV and I allergy responses [16].

On the other hand, the cell growth of human myeloid HL-60 cell line is increased by treatment with HQ or BQ [17] and the cell differentiation is inhibited by the pretreatment with $\mathrm{HQ}$ or BT prior to inducing with retinoic acid (RA) [18]. Therefore, the enhanced cell growth and GMCSF-induced colony formation or inhibited cell differentiation and apoptosis by BT treatment could be beneficial or harmful to the cells under stress [11-14]. Since BT is structurally related with sesamol, we examined whether BT had the neuroprotective effect on the activated microglia BV-2 cells under LPS or oxidative stress and on the ischemic rat brains.

\section{Methods}

Materials

LPS from Escherichia coli serotype 0111:B4 was obtained from Sigma (St Louis, MO, USA) and BT was purchased from Acros Organics (Geel, Belgium). 2', 7'-Dichlorodihydrofluorescein diacetate $\left(\mathrm{H}_{2}\right.$ DCF-DA) was obtained from Molecular Probe (Eugene, Oregon, USA).

\section{Cell culture}

The murine BV-2 cell line was maintained in DMEM supplemented with $10 \%$ FBS, $100 \mathrm{U} / \mathrm{ml}$ penicillin and $100 \mu \mathrm{g} / \mathrm{ml}$ streptomycin at $37^{\circ} \mathrm{C}$ in a humidified incubator under $5 \% \mathrm{CO}_{2}$. Confluent cultures were passed by trypsinization. For experiments, cells were washed twice with warm DMEM (without phenol red), and then treated in serum-free medium. In all experiments, cells were treated with BT for the indicated times after the addition of activating agent. BT was dissolved in phosphate-buffered saline (PBS).

\section{Cell viability assay}

The cell viability was measured with blue formazan that was metabolized from colorless 3-(4,5-dimethyl-thiazol-2-yl)-2,5-diphenyl tetrazolium bromide (MTT) by mitochondrial dehydrogenases, which were active only in live cells. BV-2 cells were preincubated in 24-well plates at a density of $5 \times 10^{5}$ cells per well for $24 \mathrm{~h}$, and then washed with PBS. Cells with various concentrations of BT were treated with LPS for $24 \mathrm{~h}$, and grown in $0.5 \mathrm{mg} / \mathrm{ml}$ MTT at $37^{\circ} \mathrm{C}$. Sixty minutes later, $200 \mu \mathrm{l}$ solubilization solution was added to each well and absorption values were read at $540 \mathrm{~nm}$ on an automated SpectraMAX 340 (Molecular Devices, Sunnyvale, CA, USA) microtiter plate reader. Data were expressed as the mean percent viable cell vs. control.

\section{Lactate dehydrogenase ( $\mathrm{LDH}$ ) release assay}

Cytotoxicity was determined by measuring the release of LDH. BV-2 cells were treated with various concentrations of BT and/or LPS for $24 \mathrm{~h}$ and the supernatant was used to assay LDH activity. The reaction was initiated by mixing $0.1 \mathrm{ml}$ of cell free supernatant with potassium 
phosphate buffer containing NADH and sodium pyruvate in a final volume of $0.2 \mathrm{ml}$ to 96 -well plate. The rate of absorbance values was read at 490/ $630 \mathrm{~nm}$ on an automated SpectraMAX 340 microtiter plate reader. Data were expressed as the mean LPS-treated cells $(100 \%)$ vs. control or BT-treated.

\section{Isolation of RNA and RT-PCR}

After treatment, total cellular RNA was extracted with a cold RNA extraction solution (Ultraspec RNA; Biotecx Laboratory Inc., Houston, TX, USA). The RT-PCR assays were performed with a Titan $^{\text {TM }}$ One Tube RT-PCR System kit (Boehringer Mannheim, Germany). Briefly, $1 \mu \mathrm{g}$ of total RNA from each sample was added to $50 \mu$ of a reaction mixture containing $0.2 \mathrm{mM}$ dNTP, $0.4 \mu \mathrm{M}$ each of sense and antisense specific primers, $5 \mathrm{mM}$ dithiothreitol (DTT), 5 U RNase inhibitor, $1 \mu \mathrm{L}$ of AMV reverse transcriptase and Expand $^{\mathrm{TM}}$ High Fidelity enzyme mix. The primer sequences are as follows: 5'-CATGGGCTTGCCC CTGGAAGTTTCTCTTCAAAG, 3'-GCAGCAT CCCCTCTGATGGTGCCATCG for iNOS (754bp fragment), and 5'-GTGGGCCGCTCTAGG CACCAA, 3'-CTCTTTGATGTCACGCACGAT TTC for $\beta$-actin (540-bp fragment), as a control for the RNA isolation and reverse-transcription. RTPCR was carried out in a Perkin-Elmer Cetus thermocycler (Norwalk, CT, USA). The preparations in the microtubes were incubated for $30 \mathrm{~min}$ at $50^{\circ} \mathrm{C}$, then amplified using a three-temperature PCR system usually consisting of denaturation at $94^{\circ} \mathrm{C}$ for $45 \mathrm{~s}$, primer annealing at $55^{\circ} \mathrm{C}$ (for iNOS) or $60^{\circ} \mathrm{C}$ (for $\beta$-actin) for $45 \mathrm{~s}$, and extension at $72^{\circ} \mathrm{C}$ for $2 \mathrm{~min}$. The number of cycles was determined for samples not reaching the amplification plateau (28 cycles for iNOS and 25 cycles for $\beta$-actin). The PCR product was visualized by electrophoresis in a $2 \%$ agarose gel, followed by staining with $0.5 \mathrm{mug} / \mathrm{ml}$ ethidium bromide. Verification of specific genes was established by their predicted size under UV light. Quantification of the band density was performed by densitometric analysis (Digital Image Analysis System, PDI, Huntington Station, NY, USA), and calculated as the optical density $\times$ area of band.

\section{Preparation of cell extracts}

The test medium was removed from culture dishes and cells were washed twice with ice-cold PBS, scraped off with a rubber policeman, and centrifuged at $200 \times g$ for $10 \mathrm{~min}$ at $4^{\circ} \mathrm{C}$. The cell pellets were resuspended in an appropriate volume (approx. $4 \times 10^{7}$ cells $\left./ \mathrm{ml}\right)$ of lysis buffer $(20 \mathrm{mM}$ Tris- $\mathrm{HCl}, \mathrm{pH} 7.5,137 \mathrm{mM} \mathrm{NaCl}, 1 \mathrm{mM}$ phenylmethylsulfonylfluoride (PMSF), $10 \mu \mathrm{g} / \mathrm{ml}$ aprotinin, $10 \mu \mathrm{g} / \mathrm{ml}$ leupeptin, and $5 \mu \mathrm{g} / \mathrm{ml}$ pepstain A), and sonicated. Protein concentration of samples was determined by Bradford assay (Bio-Rad, Hemel, Hempstead, UK) and samples equilibrated to $2 \mathrm{mg} / \mathrm{ml}$ with lysis buffer.

\section{Western blotting}

Protein samples containing $50 \mu \mathrm{g}$ of protein were separated on $12 \%$ sodium dodecyl sulfate-polyacrylamide gels and transferred to immobilon polyvinylidene difluoride membranes (Millipore, Bedford, USA). The membranes were incubated for $1 \mathrm{~h}$ with $5 \%$ dry skim milk in TBST buffer $(0.1 \mathrm{M}$ Tris- $\mathrm{HCl}, \quad \mathrm{pH} 7.4, \quad 0.9 \% \mathrm{NaCl}, \quad 0.1 \%$ Tween-20) to block non-specific binding. Then they were incubated with rabbit anti-mouse iNOS (1:2000, Calbiochem, San Diego, CA, USA), HSP70 $(1 \mu \mathrm{g} / \mathrm{ml}$, Calbiochem $), \quad \beta$-actin (1:5000, Calbiochem) and anti-phospho p38 MAPK (1:1000, Promega, Madison, WI, USA). Subsequently, the membranes were incubated with secondary antibody streptavidin-horseradish peroxidase-conjugated affinity goat anti-rabbit IgG (Jackson, West Grove, PA, USA). iNOS, $\beta$-actin, HSP70, and phosphorylated MAPK proteins were detected by a chemiluminescence detection system according to the manufacturer's instructions (ECL, Amersham, Berkshire, UK). The band intensity was quantified with a densitometric scanner (PDI, Huntington Station, NY, USA).

\section{Nitric oxide assay}

Nitrite, measured by Griess reaction, was taken as a measure of NO production. Briefly, $100 \mu \mathrm{l}$ of culture supernatant (12-24 h) was reacted with an equal volume of Griess reagent ( 1 part $0.1 \%$ naphthylethylene-diamine, 1 part $1 \%$ sulfanilamide in $5 \% \mathrm{H}_{3} \mathrm{PO}_{4}$ ) in 96-well tissue culture plates for $10 \mathrm{~min}$ at room temperature in the dark. The absorbance at $540 \mathrm{~nm}$ was determined using a microplate reader (spectraMAX 340, Molecular Devices, Sunnyvale, CA, USA). 


\section{Reactive oxygen species generation}

Intracellular accumulation of ROS was determined with $\mathrm{H}_{2} \mathrm{DCF}$-DA. This nonfluorescent compound accumulates within cells upon de-acetylation. Dichlorodihydrofluorescein $\left(\mathrm{H}_{2} \mathrm{DCF}\right)$ then reacts with ROS to form fluorescent dichlorofluorescein (DCF). BV-2 cells were plated in 96-well plates and grown for $24 \mathrm{~h}$ before addition of DMEM in the presence of $10 \mu \mathrm{M} \mathrm{H} \mathrm{H}_{2} \mathrm{DCF}-\mathrm{DA}$ for $60 \mathrm{~min}$ at $37^{\circ} \mathrm{C}$, treated with $1 \mathrm{mM} \mathrm{H} \mathrm{O}_{2}$ for $60 \mathrm{~min}$, then washed twice with room temperature HBSS (without phenol red). Cellular fluorescence was monitored on a Fluoroskan Ascent fluorometer (Labsystems Oy, Helsinki, Finland) using an excitation wavelength of $485 \mathrm{~nm}$ and emission wavelength of $538 \mathrm{~nm}$.

\section{Cell-free ROS generation}

Cell-free ROS generation was measured with $\mathrm{H}_{2} \mathrm{DCF}-\mathrm{DA}$ in the cell-free condition. $\mathrm{H}_{2} \mathrm{DCF}$ DA was dissolved in methanol and de-acetylated in cell-free medium. Sesamol $(50 \mu \mathrm{M})$ or BT (50 and $100 \mu \mathrm{M}$ ) was mixed with $10 \mu \mathrm{M} \mathrm{H} \mathrm{H}_{2} \mathrm{DCF}$ plus $1 \mathrm{mM} \mathrm{H} \mathrm{O}_{2}$ alone or with $0.1 \mathrm{mg} / \mathrm{ml} \mathrm{FeSO} \cdot 7 \mathrm{H}_{2} \mathrm{O}$ for $10 \mathrm{~min}$ in the dark. The reaction solution was plated in 96-well plates and was monitored on a Fluoroskan Ascent fluorometer. The fluorescence was measured as above.

\section{$N F-\kappa B$ assay}

To prepare nuclear extracts for $\mathrm{NF}-\kappa \mathrm{B}$ assay, the treated cells were first resuspended in buffer containing $10 \mathrm{mM}$ HEPES ( $\mathrm{pH} 7.9$ ), $1.5 \mathrm{mM} \mathrm{MgCl}_{2}$, $10 \mathrm{mM} \mathrm{KCl}, 0.5 \mathrm{mM}$ dithiothreitol, and $0.2 \mathrm{mM}$ PMSF, followed by vigorous vortex for $15 \mathrm{~s}$ before standing at $4^{\circ} \mathrm{C}$ for $10 \mathrm{~min}$; then samples were centrifuged at $2000 \mathrm{rpm}$ for $2 \mathrm{~min}$. The pelleted nuclei were resuspended in $30 \mu \mathrm{l}$ buffer containing $20 \mathrm{mM}$ HEPES (pH 7.9), 25\% glycerol, $420 \mathrm{mM}$ $\mathrm{NaCl}, 1.5 \mathrm{mM} \mathrm{MgCl}_{2}, 0.2 \mathrm{mM}$ EDTA, $0.5 \mathrm{mM}$ dithiothreitol, and $0.2 \mathrm{mM}$ PMSF and incubated for $20 \mathrm{~min}$ on ice, and nuclear lysates were then centrifuged at 15,000 rpm for $2 \mathrm{~min}$. Supernatants containing the solubilized nuclear proteins were stored at $-70{ }^{\circ} \mathrm{C}$ for subsequent $\mathrm{NF}-\kappa \mathrm{B}$ assay. NF$\kappa \mathrm{B}$ activity was measured by a NF- $\kappa \mathrm{Bp} 65 \mathrm{AC}-$ TIVELISA kit (BIOCARTA, Carlsbad, CA, USA) according the manufacturer's instruction. The absorbance at $405 \mathrm{~nm}$ was determined using a microplate reader (spectraMAX 340).

\section{Infarction assay}

Twenty male Sprague-Dawley (SD) rats (200$250 \mathrm{gm})$ were purchased from National Animal Center, Taipei and randomly divided into the control (saline), and BT groups. The experiment was approved by Animal Study Protocol Review of Taichung Veterans General Hospital. Each SD rat was anesthetized with chlorohydrate $(400 \mathrm{mg}$ / $\mathrm{kg}$ ) intraperitoneally and its body temperature was maintained at $37^{\circ} \mathrm{C}$ with a heating pad (CMA/ 150). A midline neck incision was made and the right carotid artery was exposed and separated from the vago-sympathetic trunk. The right carotid artery was loosely encircled with a 4-O suture for later occlusion. The SD rat's head was placed in a stereotaxic frame (David Kopf, CA, USA) with the nose bar positioned $4.0 \mathrm{~mm}$ below the horizontal line. Following a midline incision, the skull was partially removed to expose the right middle cerebral artery. The middle cerebral artery was loosely encircled with an 8-O suture for later occlusion. A focal cerebral ischemia was induced by occlusion of the right common carotid artery and the right cerebral artery (CCA + MCA) for $60 \mathrm{~min}$, followed by reperfusion. A laser probe ( $0.8 \mathrm{~mm}$ in diameter) of a Laser Doppler Blood Flow monitor (MBF 3D, Moor Instruments, Axminster, England) was positioned onto the cortex with its tip close to the middle cerebral artery. Cerebral blood flow dropped to less than $5 \%$ of basal after the occlusion of the MCA. Cerebral blood flow reached its minimal levels within 5 min after the start of the occlusion and was confirmed to remain at this level throughout the monitoring period to ensure the validity of the stroke model. BT was injected intravenously at the thigh vein after occlusion of the MCA occlusion.

Twenty-four hours after cerebral ischemia, each SD rat was anesthetized and perfused transcardially with isotonic heparinized saline and 2,3,5triphenyltetrazolium chloride (TTC). The brain was then removed and sliced into five 2-mm-thick coronal sections for TTC staining as described by Bederson et al. (19). All TTC data were analyzed by ANOVA with Student's $t$ - tests. $P<0.05$ was considered to be statistically significant. 


\section{Statistical analysis}

All data were expressed as the mean \pm SEM. For single variable comparisons, Student's $t$-test was used. For multiple variable comparisons, data were analyzed by one-way analysis of variance (ANOVA) followed by Scheffe's test. $P$-values less than 0.05 were considered significant.

\section{Results}

Inhibition of NO production by BT

The effects of BT on NO production in LPSstimulated BV-2 were investigated. The cells were treated with LPS alone or with various concentrations of BT for $12-24 \mathrm{~h}$. NO production was assayed by measuring the levels of a stable NO metabolite, nitrite in the conditioned medium. At the concentrations $(10-100 \mu \mathrm{M})$ used in this study, none of the LPS or BT treatments caused toxicity to cells as judged by the MTT and LDH assays (Figure 2). BT treatment of BV-2 cells after LPS stimulation dose-dependently decreased nitrite accumulation. BT at $100 \mu \mathrm{M}$ concentration effectively inhibited NO production by $70 \%$ before $20 \mathrm{~h}$ of culturing time in LPS-stimulated BV2 cells (Figure 3 ).

\section{Inhibition of iNOS by BT}

To determine whether the inhibitory ability of BT on NO production was due to a decrease in the cytosolic iNOS protein level, BV-2 cells were treated with LPS and BT for $16 \mathrm{~h}$, and the levels of iNOS protein were detected by Western blotting. As shown in Figure 4, treatment with BT, similar to sesamol, led to a significant decrease in iNOS protein levels. BT $(50-100 \mu \mathrm{M})$ inhibited LPS-induced iNOS protein production by 50 $60 \%$.

\section{Suppression of iNOS mRNA accumulation by $B T$}

RT-PCR analyses were performed to assess the effect of BT on iNOS mRNA steady-state levels. BV-2 cells were treated with various concentrations of BT and LPS for $4 \mathrm{~h}$. As shown in Figure 5, accumulation of iNOS mRNA levels was suppressed by BT. Similar to sesamol, treatment with
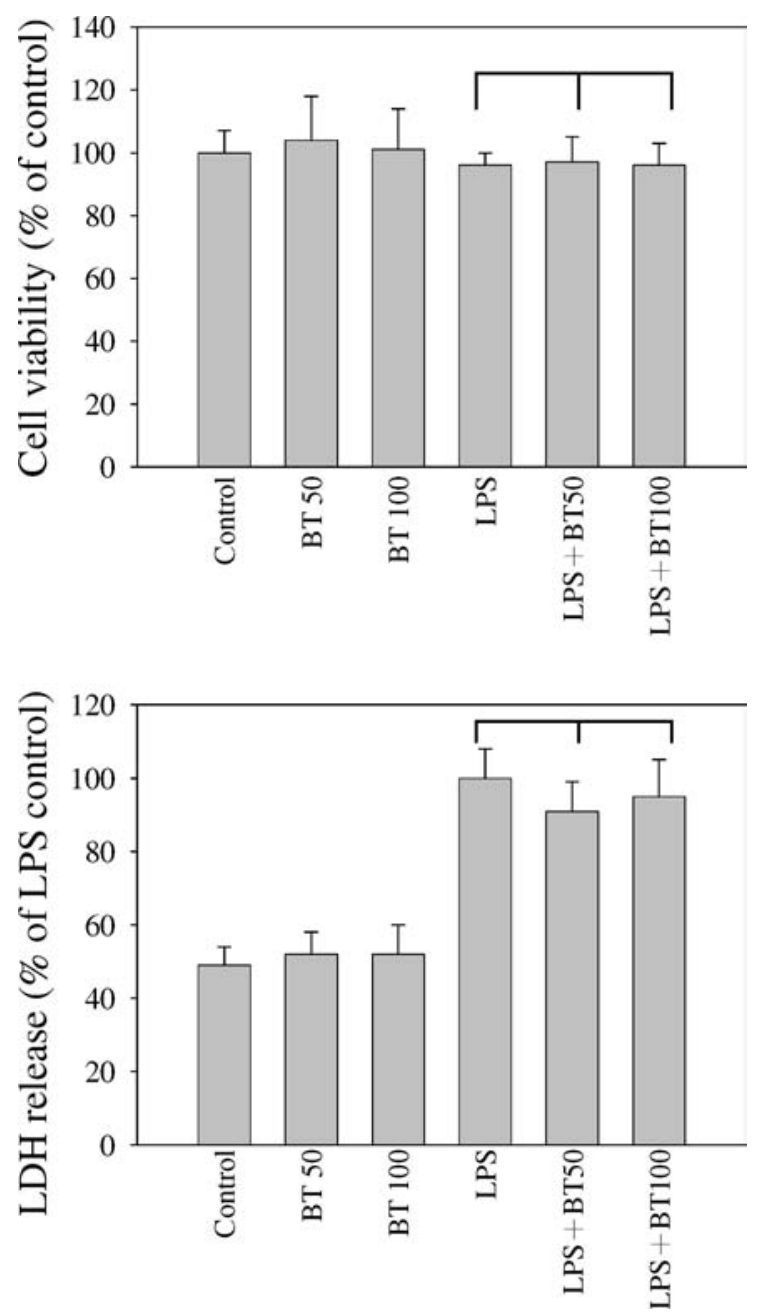

Figure 2. Effect of BT on the cell viability and cytotoxicity in LPS-stimulated BV-2 microglia. Cells were treated with $1 \mu \mathrm{g} /$ $\mathrm{ml}$ LPS then various concentrations of BT $(50$ and $100 \mu \mathrm{M})$ were added for $24 \mathrm{~h}$. BT was not toxic to BV-2 cells with or without LPS (a) or increased the LDH released (b) as compared with BV-2 cells with LPS. ${ }^{*} p>0.05$.

higher concentrations of BT resulted in a significant decrease in LPS-induced iNOS mRNA levels.

\section{BT inhibited LPS-induced p38 MAPK activation}

To further evaluate whether the MAPK signaling pathways are involved in the induction of iNOS, we examined the ability of LPS to activate each of the three MAPKs in BV-2 cells. We previously showed that LPS activated p38 and JNK, but not ERK MAPK. The phosphorylation of p38 reached a maximum between 15 and $20 \mathrm{~min}$ and 


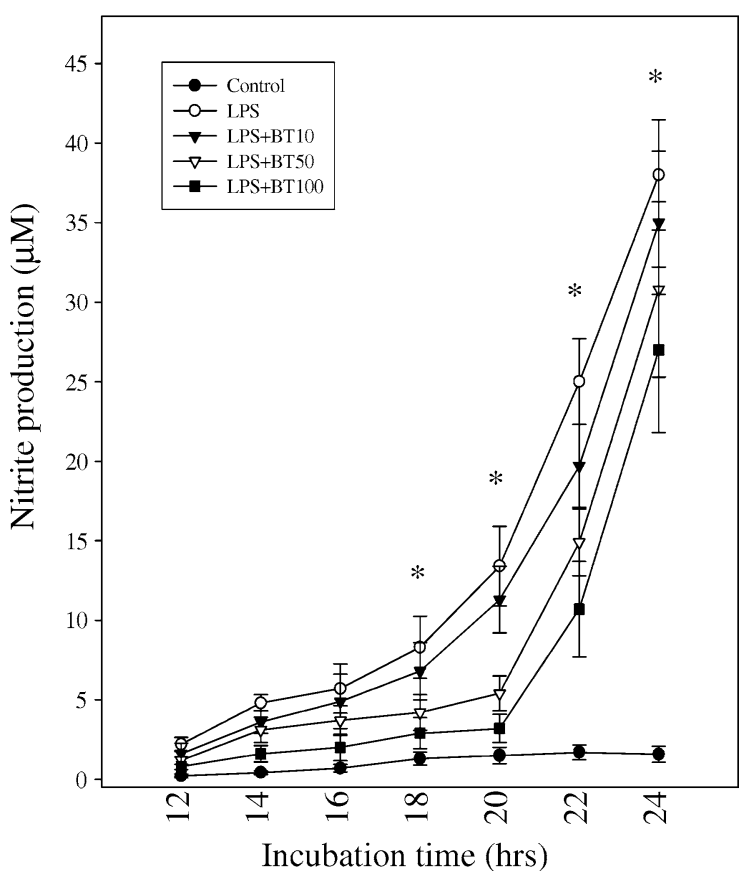

Figure 3. Effect of BT on nitrite production in LPS-stimulated BV-2 microglia. Cells were treated with $1 \mu \mathrm{g} / \mathrm{ml}$ LPS then various concentrations of BT $(10,50$ and $100 \mu \mathrm{M})$ were added for $24 \mathrm{~h}$. Nitrite content was measured using the Griess reaction. Values indicate nitrite production from culture supernatants of LPS treated alone and cells exposed to LPS plus BT. Values represent the mean \pm SEM of five separate experiments on $\mathrm{BV}-2$ microglia. ${ }^{*} p \leq 0.05$.

JNK remained high for $120 \mathrm{~min}$ [15]. These results were consistent with observations that only p38 MAPK inhibitor (SB203580) could inhibit LPSinduced NO production [15]. Similar to sesame antioxidants [20], BT at a concentration of 50$100 \mu \mathrm{M}$, significantly decreased (50-70\%) LPSactivated p38 MAPK (Figure 6).

\section{BT suppressed LPS-induced NF- $\kappa B$ activation}

The NF- $\kappa \mathrm{B}$ activity was assayed by an ELISA kit. As shown in Figure 7, BT and sesamol, which has a similar chemical structure, inhibited the LPSinduction of specific NF- $\kappa \mathrm{B}$ activity. Both agents could inhibit LPS-induced NF- $\kappa \mathrm{B}$ activation by $30-40 \%$ at the concentration of $50 \mu \mathrm{M}$.

\section{ROS scavenging effect of sesamol and BT}

The scavenging effect of sesamol and BT on ROS generation in a cell-free condition was assessed

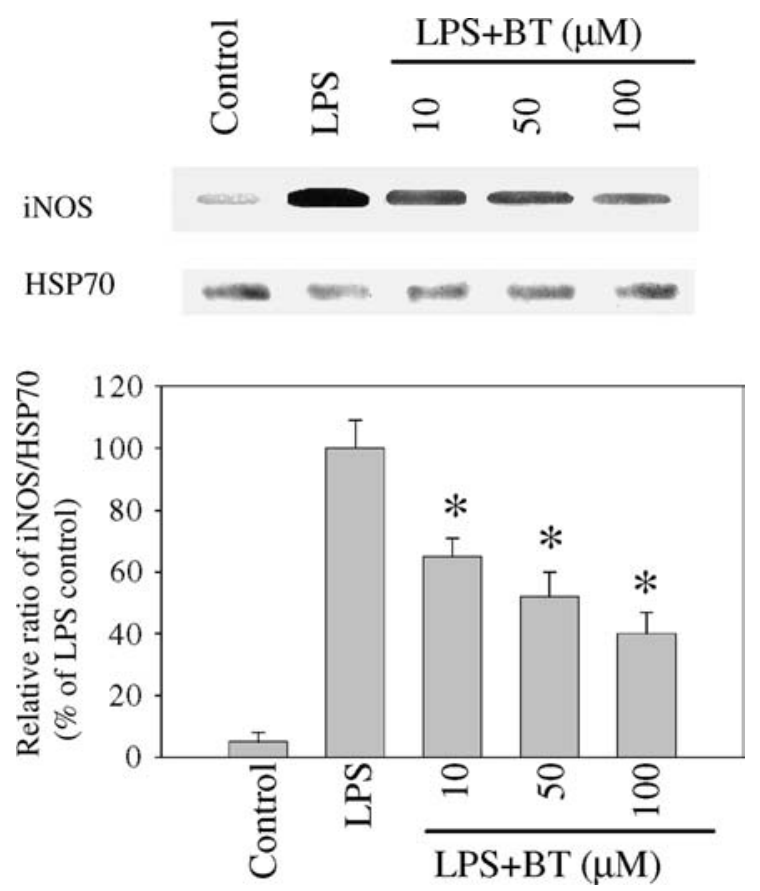

Figure 4. Modulation of LPS-induced iNOS expression by BT. Cell lysates were prepared and subjected to Western blotting from control or cell stimulated with $1 \mu \mathrm{g} / \mathrm{ml} \mathrm{LPS}$, alone or in combination with increasing concentrations (10,50 and $100 \mu \mathrm{M})$ of BT for $16 \mathrm{~h}$. Depicted is a represented data of iNOS protein expression (upper panel) and the statistical analysis of the changes of iNOS protein (lower panel). Data represent the mean $\pm \mathrm{SEM}$ of three independent experiments. $* p \leq 0.05$.

with $\mathrm{H}_{2} \mathrm{O}_{2}$ alone or with $\mathrm{FeSO}_{4} \cdot 7 \mathrm{H}_{2} \mathrm{O}$. Sesamol at the concentration of $50 \mu \mathrm{M}$ was able to reduce ROS generation by $\mathrm{H}_{2} \mathrm{O}_{2}(1 \mathrm{mM})$ alone or with $\mathrm{FeSO}_{4} \cdot 7 \mathrm{H}_{2} \mathrm{O}(0.1 \mathrm{mg} / \mathrm{ml})$. BT dose-dependently scavenged ROS generation (Figure 8).

\section{BT reduced $\mathrm{ROS}$ generation in $\mathrm{H}_{2} \mathrm{O}_{2}$-stimulated microglia}

The effect of BT on ROS generation in BV-2 cells was assessed with an oxidative stress inducer. Treatment of BV-2 cells with $\mathrm{H}_{2} \mathrm{O}_{2}(0.1,1$, $10 \mathrm{mM}$ ) dose-dependently increased the release of ROS significantly from $30 \mathrm{~min}$ and maximally at $2 \mathrm{~h}$ (data not shown). BT was able to reduce the generation of ROS by $\mathrm{H}_{2} \mathrm{O}_{2}(1 \mathrm{mM})$ in $\mathrm{BV}-2$ cells, and dose-dependently diminished ROS generation (Figure 9). In contrast, sesamol at the lower concentrations diminished ROS generation but increased ROS by auto-oxidation at the higher concentration. 

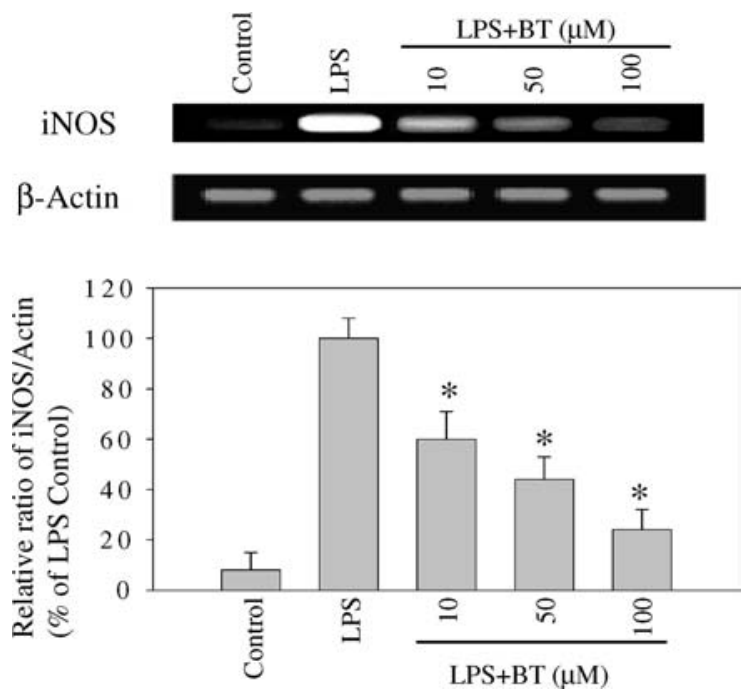

Figure 5. Effect of BT on the LPS-induced iNOS mRNA in BV-2 microglia. Cells were treated with $1 \mu \mathrm{g} / \mathrm{ml}$ LPS and various concentrations of BT for $4 \mathrm{~h}$. Levels of iNOS and $\beta$-actin mRNA were assayed by RT-PCR analysis. Representive data are selected from three independent experiments (upper panel) and the statistical analysis of the ratios of iNOS $/ \beta$-actin mRNA (lower panel). ${ }^{*} p \leq 0.05$.

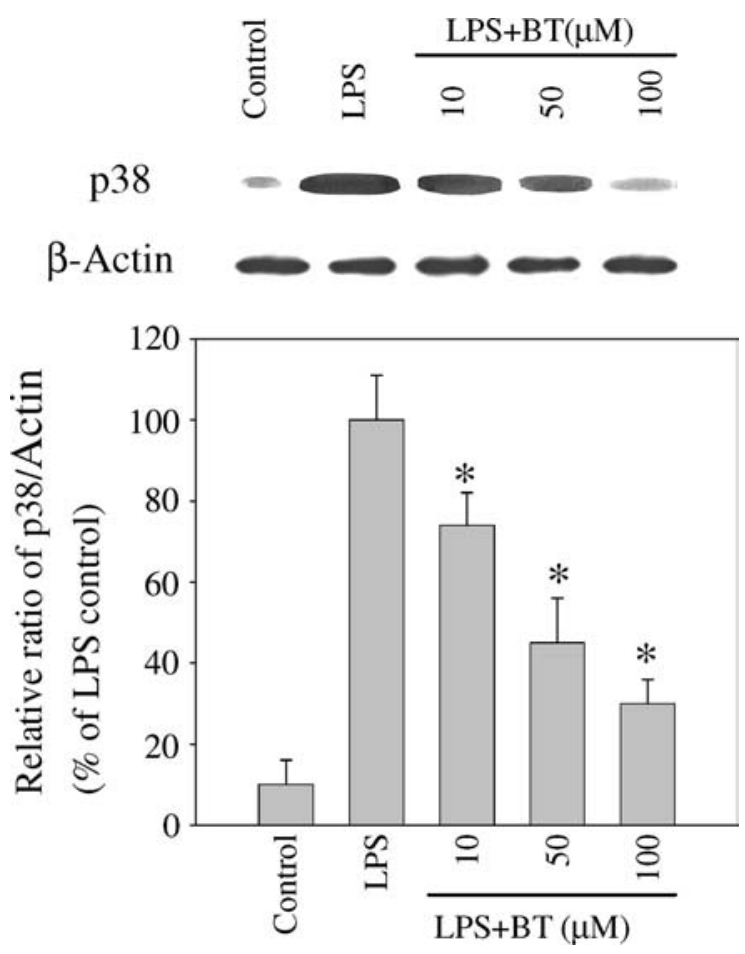

Figure 6. Effect of BT on LPS-induced p38 MAP kinases in BV-2 microglia. BV-2 microglia cell lysates were prepared from control or $1 \mu \mathrm{g} / \mathrm{ml}$ LPS-stimulated cells, alone or in combination with $10,50,100 \mu \mathrm{M}$ of BT for $20 \mathrm{~min}$. Results are representative of the mean \pm SEM of three independent experiments. ${ }^{*} p \leq 0.05$.

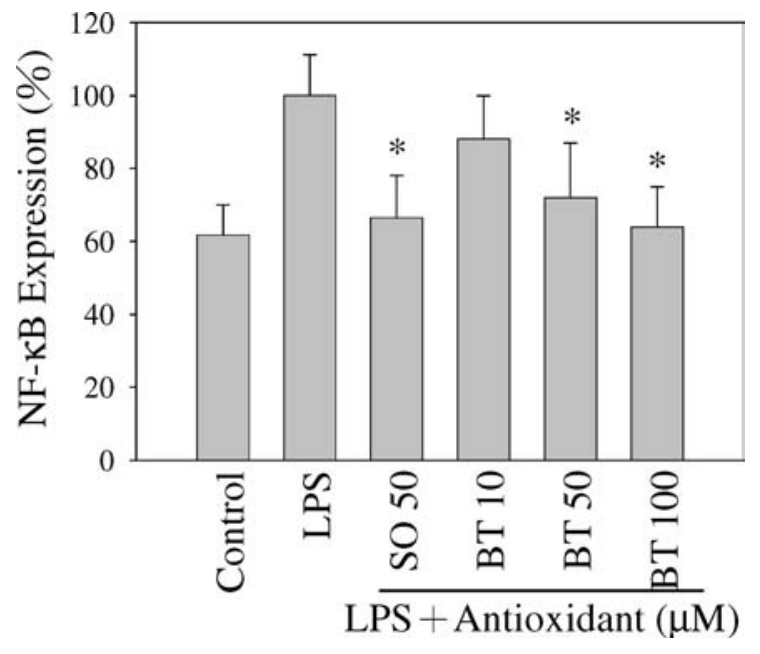

Figure 7. Effect of BT on LPS-induced NF- $\kappa \mathrm{B}$ activity in BV2 microglia. BV-2 cells were treated with $1 \mu \mathrm{g} / \mathrm{ml}$ LPS for $4 \mathrm{~h}$, pretreated with sesamol $50 \mu \mathrm{M}$ for $4 \mathrm{~h}$ or in combination with $10,50,100 \mu \mathrm{M}$ of BT. NF- $\kappa \mathrm{B}$ activity was measured by an ELISA kit. Values represent the mean \pm SEM of three independent experiments. ${ }^{*} p \leq 0.05$, indicate significant differences between LPS alone and LPS plus sesamol or BT.

\section{Effect of BT on the ischemic brain}

In order to determine the neuroprotective effect of BT, SD rats were subjected to focal cerebral ischemia prior to administering BT. BT given after $1 \mathrm{~h}$ of ischemia, significantly reduced the infarct volume (by $40 \%$ ) as compared to the control group. All animals had infarcts in the cortex and caudateputamen. Infarct volumes were determined by TTC staining. Typical infarct sizes for each group are shown in Figure 10 as visualized by TTC staining.

\section{Discussion}

In the present study, we found that BT, similar to sesamol, significantly inhibited LPS-stimulated NO production, iNOS mRNA and protein expression in BV-2 microglia. Furthermore, BT was able to inhibit $\mathrm{H}_{2} \mathrm{O}_{2}$-induced $\mathrm{ROS}$ generation and protect the ischemic rat brain under middle cerebral artery occlusion.

At the concentrations of $10-100 \mu \mathrm{M}$ in this study, BT treatments caused no further cytotoxicity than BV-2 cells with LPS alone (Figure 2). Previously, treatment with low concentrations (20$40 \mu \mathrm{g} / \mathrm{ml}$ ) of HQ to HL-60 cells have shown an enhanced cell growth and cell cycle kinetics instead 

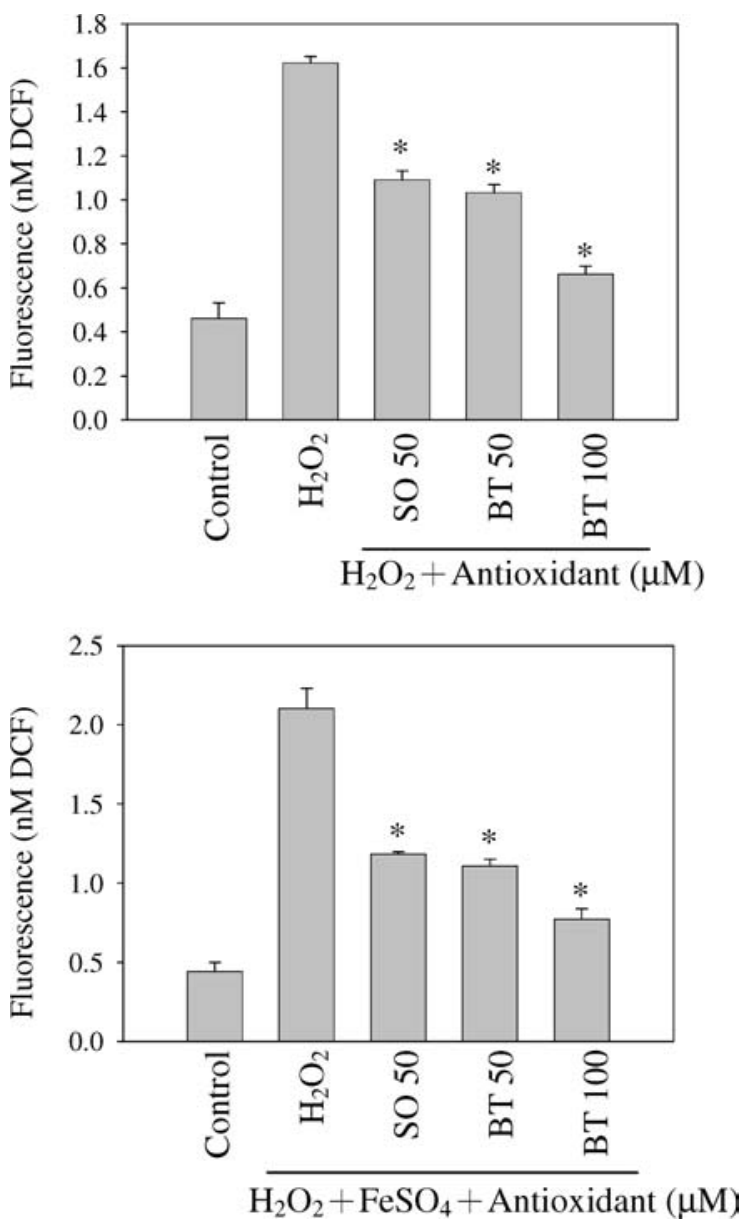

Figure 8. Effect of BT on ROS generation in cell-free condition. The scavenging effect of BT on ROS generation in cellfree condition was assessed with $\mathrm{H}_{2} \mathrm{O}_{2}(1 \mathrm{mM})$ alone or with addition of $\mathrm{FeSO}_{4} \cdot 7 \mathrm{H}_{2} \mathrm{O}(0.1 \mathrm{mg} / \mathrm{ml})$. BT dose-dependently scavenged ROS generation in $\mathrm{H}_{2} \mathrm{O}_{2}$ either with or without $\mathrm{FeSO}_{4} \cdot 7 \mathrm{H}_{2} \mathrm{O}$. ${ }^{*} p \leq 0.05$.

of cytotoxic [17]. Treatment with 12.5-200 $\mu \mathrm{M} \mathrm{HQ}$ did not cause human lymphocyte mutagenic [21]. These results are in contrast to other studies that show benzene metabolites and BT are readily oxidized and formed active oxygen species that damage naked DNA and other cellular macromolecules. Particularly, BT causes DNA strand breakage [22] and increases the frequency of micronuclei (MN) formation twofold in lymphocytes and eightfold in HL-60 cells [23]. The BT concentration in this study is not cytotoxic to BV-2 cells, it needs to be confirm on the other type of cells.

BT treatment of BV-2 cells after LPS stimulation dose-dependently decreased nitrite accumulation. Excessive NO and ROS production in the

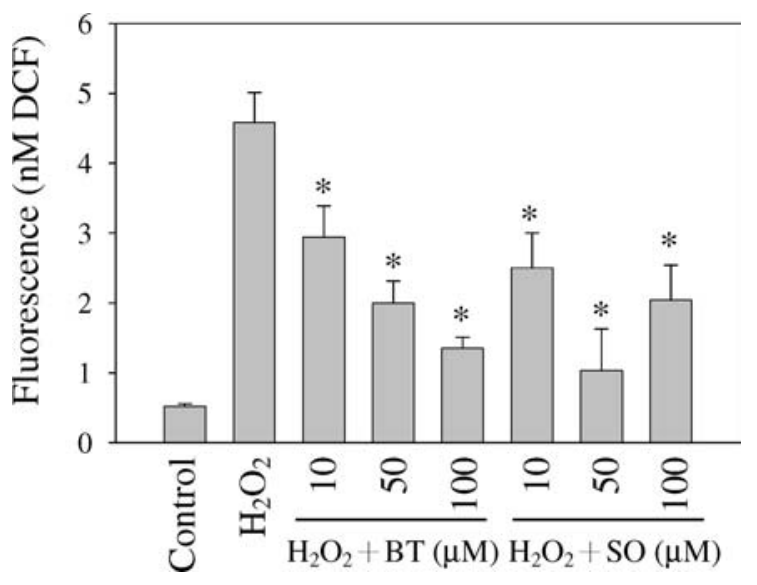

Figure 9. Effect of sesamol or BT on ROS production in $\mathrm{H}_{2} \mathrm{O}_{2}$-stimulated BV-2 microglia. Cells were treated with $1 \mathrm{mM} \mathrm{H}_{2} \mathrm{O}_{2}$, followed by addition of various concentrations of BT and sesamol $(10,50$ and $100 \mu \mathrm{M})$ for $1 \mathrm{~h}$. Cellular fluorescence was monitored on a Fluoroskan Ascent fluorometer. ${ }^{*} p<0.01$, as compared with cells treated with $\mathrm{H}_{2} \mathrm{O}_{2}$. Values represent the mean \pm SEM of four independent experiments.

brain are believed to contribute to neurodegenerative processes [24-26]. Various dietary-derived polyphenolic compounds that inhibit the LPSinduced NO production may have neuroprotective potential $[15,20,27]$. We found that BT at concentrations of $50-100 \mu \mathrm{M}$ inhibited $50-70 \%$ of LPS-stimulated iNOS mRNA expression and $70 \%$ of $\mathrm{NO}$ production in BV-2 microglia. The reduction in LPS-induced iNOS protein expression by BT was proportional to their reduction of iNOS mRNA. Therefore, the decrease of iNOS protein by BT was similar to sesamol and other sesame lignans that also decrease in the transcription and translation of the LPS-induced iNOS gene [20]. This result is in agreement with a previous study that showed $\mathrm{BQ}$ and $\mathrm{HQ}$, but not BT, increase NO production from HL-60 cells under phorbol ester stimulation [28]. BT at concentrations of 50 and $100 \mu \mathrm{M}$ inhibit Fc receptor-mediated phagocytosis by 70 and $95 \%$, respectively. In comparison, HQ only at the concentration of $100 \mu \mathrm{M}$ decrease $50 \%$ of phagocytosis [28].

Inhibition of $\mathrm{p} 38$ MAPK can be expected to be beneficial in injuries involving microglia activation and inflammation. Specific inhibitors of p38 MAPK have been proven to reduce inflammation, slow down microglia activation and provide neuroprotective effects [15, 30-32]. Recently, studies have shown that compounds that inhibit p38 

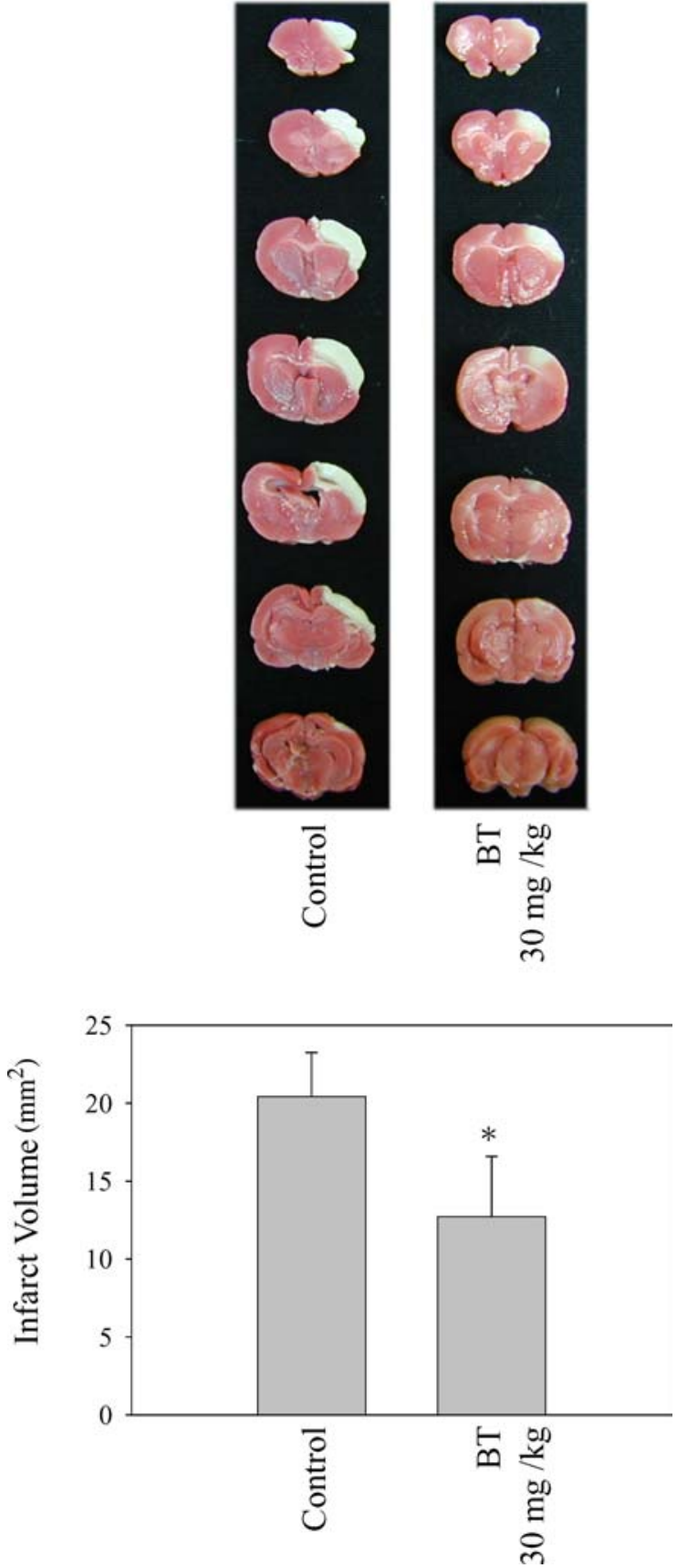

Figure 10. Effect of BT on the ischemic rat brains. Mean infarct volume was determined by TTC staining in SD rats subjected to $1 \mathrm{~h} \mathrm{MCA}+\mathrm{CCA}$-occlusion followed by reperfusion for $23 \mathrm{~h}$. Treatments of BT $(30 \mathrm{mg} / \mathrm{kg})$ or saline ( $n=10$, for each group) were initiated $1 \mathrm{~h}$ after the MCA + CCA-occlusion. Data is expressed as the mean \pm SEM of infarct volumes. ${ }^{*} p<0.05$, as compared with the control group by Student's $t$-test.

MAPK activation in microglia represent potential anti-inflammatory effects and protect neurons against excitotoxicity or LPS-induced neurotoxic- ity $[9,20,33]$. In this study, possible neuroprotective mechanisms relating to MAP kinases or inhibition of NO production by BT in LPS-treated microglia cells were explored. Our previous results showed that LPS could induce the activation of p38 and JNK, but not ERK1/ERK2 MAPK [15]. The phosphorylation of p38 increased with time, reaching a maximum between 15 and $20 \mathrm{~min}$. These results were consistent with the observation that only p38 MAPK inhibitor could inhibit LPSinduced NO production $[15,20]$. BT significantly suppressed LPS-induced p38 MAPK expression $(30-70 \%)$. Therefore, the results of p38 MAPK inhibition by BT correlated very well with their effects on iNOS/NO inhibition. Thus, the mechanism of inhibition of LPS-induced iNOS expression by BT might be similar to sesamol and other polyphenol antioxidants that selectively inhibit p38 MAPK [20, 34].

Previous studies show that neuroprotective effects of antioxidants are due to increasing antioxidant enzyme, intracellular glutathione, lowering of ROS, and preventing calcium release [20, 35-37]. We suspected that protective effects on NO production by these agents might be due in part to differences in their ROS scavenging effect based on their structures.

ROS can damage important biomolecules but also function as second messengers to activate MAPK, and the nuclear transcription factors cJun and NF- $\kappa$ B [38-40]. Similar intracellular signaling mechanisms related to the effect of LPS have been studied in microglia $[15,41]$. The observations imply that all these could be downstream of ROS signaling and have been considered as common signaling pathways involved in microglia activation [42]. Thus ROS could have dual roles in microglia as cytotoxic mediators as well as signaling molecules.

BT may be able to down-regulate LPS-induced inflammatory factor production via the inhibition of ROS generation which subsequently reduces the activation of NF- $\kappa \mathrm{B}$ and cytokine gene activation $[43,44]$. The abilities of BT to inhibit the LPSinduced iNOS mRNA/protein might be due to decreased gene transcription/translation via the attenuation of ROS signal, and reduced NF- $\kappa \mathrm{B}$ and p38 MAPK activities.

NF- $\kappa$ B is an important transcription factor for proinflammatory cytokines in LPS-stimulated microglia $[45,46]$. The interference with $\mathrm{NF}-\kappa \mathrm{B}$ 
transcriptional activity in the microglial nucleus can suppress iNOS mRNA and protein [47]. We showed that both BT and sesamol inhibited the LPS-induced NF- $\kappa \mathrm{B}$ activation and iNOS mRNA and protein (Figure 7 and [20]). In addition, we found that BT did scavenge ROS similar to it in a cell-free condition with $\mathrm{H}_{2} \mathrm{O}_{2}$ plus $\mathrm{Fe}^{2+}$ producing $\mathrm{OH}^{-}$and $\mathrm{OH}$ (Fenton reaction) (Figure 8). In contrast, ROS production by benzene metabolites, BQ, BT and phenol was demonstrated in HL60 cells in vitro [48]. The discrepancy of different responses to BT may be caused by the cells with different level of antioxidant enzymes derived from different species [49].

The neuroprotective effect of BT was demonstrated in SD rats subjected to focal cerebral ischemia. Rats with acute treatment with BT after ischemia, significantly reduced the infarct volume (about 40\%) as compared to the control group. Although the precise mechanism of neuroprotection is not clear, the combined results of in vitro and in vivo experiments suggest the reduction of neuronal injury might involve inhibition of the release of NO or ROS during cerebral ischemia.

In conclusion, the present results show that BT inhibited NO production in LPS-stimulated BV-2 microglia. The mechanism(s) of BT inhibition of the LPS-induced iNOS mRNA/protein involve the NF- $\kappa \mathrm{B}$, p38 MAPK signal pathway and/or antioxidative activity. However, further studies are required to confirm the importance of the cellular antioxidant activity of BT in the MAPK signaling pathway. Nevertheless, these results extend our knowledge of BT and its role in microglia activation and therapeutic potential.

\section{Acknowledgements}

This study was supported by NSC912320B075A003 grant from the National Science Council of ROC (K.C.J.).

\section{References}

1. Hou R.C., Wu C.C., Yang C.H. and Jeng K.C., Protective effects of sesamin and sesamolin on murine BV-2 microglia cell line under hypoxia. Neurosci. Lett. 367: 10-13, 2004.

2. Hou R.C., Huang H.M., Tzen J.T. and Jeng K.C., Protective effects of sesamin and sesamolin on hypoxic neuronal and PC12 cells. J. Neurosci. Res. 74: 123-133, 2003.
3. Hiramoto K., Li X., Makimoto M., Kato T. and Kikugawa $\mathrm{K}$., Identification of hydroxyhydroquinone in coffee as a generator of reactive oxygen species that break DNA single strands. Mutat. Res. 419: 43-51, 1998.

4. Greenlee W.F., Chism J.P. and Rickert D.E., A novel method for the separation and quantitation of benzene metabolites using high-pressure liquid chromatography. Anal. Biochem. 112: 367-370, 1981.

5. Inoue O., Seiji K., Nakatsuka H., Watanabe T., Yin S., Li G.L., Cai S.X., Jin C. and Ikeda M., Excretion of 1,2,4benzenetriol in the urine of workers exposed to benzene. $\mathrm{Br}$. J. Ind. Med. 46: 559-565, 1989.

6. Qu Q., Melikian A.A., Li G., Shore R., Chen L., Cohen B., Yin S., Kagan M.R., Li H., Meng M., Jin X., Winnik W., $\mathrm{Li} \mathrm{Y.,} \mathrm{Mu} \mathrm{R.} \mathrm{and} \mathrm{Li} \mathrm{K.,} \mathrm{Validation} \mathrm{of} \mathrm{biomarkers} \mathrm{in}$ humans exposed to benzene: urine metabolites. Am. J. Ind. Med. 37: 522-531, 2000.

7. Hiramoto K., Kida T. and Kikugawa K., Increased urinary hydrogen peroxide levels caused by coffee drinking. Biol. Pharm. Bull. 25: 1467-1471, 2002.

8. Halliwell B., Long L.H., Yee T.P., Lim S. and Kelly R., Establishing biomarkers of oxidative stress: the measurement of hydrogen peroxide in human urine. Curr. Med. Chem. 11: 1085-1092, 2004.

9. Li A.S., Bandy B., Tsang S. and Davison A.J., DNA breakage induced by 1,2,4-benzenetriol: relative contributions of oxygen-derived active species and transition metal ions. Free Radic. Biol. Med. 30: 943-956, 2001.

10. Akagawa M., Shigemitsu T. and Suyama K., Production of hydrogen peroxide by polyphenols and polyphenol-rich beverages under quasi-physiological conditions. Biosci. Biotechnol. Biochem. 67: 2632-2640, 2003.

11. Huang H. and Manton K.G., The role of oxidative damage in mitochondria during aging: a review. Front. Biosci. 9: 1100-1117, 2004.

12. Droge W., Free radicals in the physiological control of cell function. Physiol. Rev. 82: 47-95, 2002.

13. Rao G.S., Siddiqui S.M., Pandya K.P. and Shanker R., Relative toxicity of metabolites of benzene in mice. Vet. Hum. Toxicol. 30: 517-520, 1988.

14. Laskin J.D., Rao N.R., Punjabi C.J., Laskin D.L. and Synder R., Distinct actions of benzene and its metabolites on nitric oxide production by bone marrow leukocytes. J. Leukoc. Biol. 57: 422-426, 1995.

15. Wang M.J., Lin W.W., Chen H.L., Chang Y.H., Ou H.C., Kuo J.S., Hong J.S. and Jeng K.C.G., Silymarin protects dopaminergic neurons against lipopolysaccharide-induced neurotoxicity by inhibiting microglia activation. Eur. J. Neurosci. 16: 2103-2112, 2002.

16. Mi H., Hiramoto K., Kujirai K., Ando K., Ikarashi Y. and Kikugawa K., Effect of food reductones, 2,5-dimethyl-4hydroxy-3(2H)-furanone (DMHF) and hydroxyhydroquinone (HHQ), on lipid peroxidation and type IV and I allergy responses of mouse. J. Agric. Food Chem. 49: 4950 4955, 2001.

17. Wiemels J. and Smith M.T., Enhancement of myeloid cell growth by benzene metabolites via the production of active oxygen species. Free Radic. Res. 30: 93-103, 1999.

18. Hedli C.C., Rao N.R., Reuhl K.R., Witmer C.M. and Snyder R., Effects of benzene metabolite treatment on granulocytic differentiation and DNA adduct formation in HL-60 cells. Arch. Toxicol. 70: 135-144, 1996.

19. Bederson J.B., Pitts L.H., Germano S.M., Nishimura M.C., Davis R.L. and Bartkowski H.M., Evaluation of 2,3,5- 
triphenyltetrazolium chloride as a strain for detection and quantification of experimental cerebral infarction in rats. Stroke 17: 1304-1308, 1986.

20. Hou R.C., Chen H.L., Tzen J.T. and Jeng K.C., Effect of sesame antioxidants on LPS-induced NO production by BV2 microglial cells. Neuroreport 14: 1815-1819, 2003.

21. Doepker C.L., Dumont K.W., O'Donoghue J. and English J.C., Lack of induction of micronuclei in human peripheral blood lymphocytes treated with hydroquinone. Mutagenesis 15: 479-487, 2000.

22. Li A.S., Bandy B., Tsang S.S. and Davison A.J., DNAbreaking versus DNA- protecting activity of four phenolic compounds in vitro. Free Radic. Res. 33: 551-566, 2000.

23. Zhang L., Robertson M.L., Kolachana P., Davison A.J. and Smith M.T., Benzene metabolite, 1,2,4-benzenetriol, induces micronuclei and oxidative DNA damage in human lymphocytes and HL60 cells. Environ. Mol. Mutagen. 21: 339-348, 1993.

24. Peterson P.K., Hu S., Anderson W.R. and Chao C.C., Nitric oxide production and neurotoxicity mediated by activated microglia from human versus mouse brain. J. Infect. Dis. 170: 457-460, 1994.

25. Lu F., Selak M., O'Connor J., Croul S., Lorenzana C., Butunoi C. and Kalman B., Oxidative damage to mitochondrial DNA and activity of mitochondrial enzymes in chronic active lesions of multiple sclerosis. J. Neurol. Sci. 177: 95-103, 2000.

26. Chao C.C., Hu S., Molitor T.W., Shaskan E.G. and Peterson P.K., Activated microglia mediate neuronal cell injury via a nitric oxide mechanism. J. Immunol. 149: 27362741, 1992.

27. Sun A.Y. and Chen Y.M., Oxidative stress and neurodegenerative disorders. J. Biomed. Sci. 5: 401-414, 1998.

28. Rao N.R. and Snyder R., Oxidative modifications produced in HL-60 cells on exposure to benzene metabolites. J. Appl. Toxicol. 15: 403-409, 1995.

29. Manning B.W., Adams D.O. and Lewis J.G., Effects of benzene metabolites on receptor-mediated phagocytosis and cytoskeletal integrity in mouse peritoneal macrophages. Toxicol. Appl. Pharmacol. 126: 214-223, 1994.

30. Tikka T.M. and Koistinaho J.E., Minocycline provides neuroprotection against N-methyl-D-aspartate neurotoxicity by inhibiting microglia. J. Immunol. 166: 7527-7533, 2001.

31. Maruyama M., Sudo T., Kasuya Y., Shiga T., Hu B. and Osada H., Immunolocalization of p38 MAP kinase in mouse brain. Brain Res. 887: 350-358, 2000.

32. Woo M.S, Jang P.G., Park J.S., Kim W.K., Joh T.H. and Kim H.S., Selective modulation of lipopolysaccharidestimulated cytokine expression and mitogen-activated protein kinase pathways by dibutyryl-cAMP in BV2 microglial cells. Brain Res. Mol. Brain Res. 113: 86-96, 2003.

33. Bodles A.M. and Barger S.W., Secreted beta-amyloid precursor protein activates microglia via JNK and p38MAPK. Neurobiol. Aging 26: 9-16, 2005.

34. Wadsworth T.L and Koop D.R., Effects of Ginkgo biloba extract (EGb 761) and quercetin on lipopolysaccharideinduced release of nitric oxide. Chem. Biol. Interact. 137: $43-58,2001$

35. Bastianetto S. and Quirion R., Natural antioxidants and neurodegenerative diseases. Front. Biosci. 9: 3447-3452, 2004.
36. Rosenstock T.R., Carvalho A.C., Jurkiewicz A. and Frussa-Filho R., and Smaili S.S., Mitochondrial calcium, oxidative stress and apoptosis in a neurodegenerative disease model induced by 3-nitropropionic acid. J. Neurochem. 88: 1220-1228, 2004.

37. Anderson M.F., Nilsson M., Eriksson P.S. and Sims N.R., Glutathione monoethyl ester provides neuroprotection in a rat model of stroke. Neurosci. Lett. 354: 163165, 2004.

38. Park J.Y., Kim E.J., Kwon K.J., Jung Y.S., Moon C.H., Lee S.H. and Baik E.J., Neuroprotection by fructose-1,6bisphosphate involves ROS alterations via p38 MAPK/ ERK. Brain Res. 1026: 295-301, 2004.

39. Katoh S., Mitsui Y., Kitani K. and Suzuki T., Hyperoxia induces the neuronal differentiated phenotype of PC12 cells via a sustained activity of mitogen-activated protein kinase induced by Bcl-2. Biochem. J. 338: 465-470, 1999.

40. Tanaka S., Takehashi M., Matoh N., Lida S., Suzuki T., Futaki S., Hamada H., Masliah E., Sugiura Y. and Ueda $\mathrm{K}$., Generation of reactive oxygen species and activation of $\mathrm{NF}-\kappa \mathrm{B}$ by non-A $\beta$ component of Alzheimer's disease amyloid. J. Neurochem. 82: 305-315, 2002.

41. Bhat N.R., Zhang P., Lee J.C. and Hogan E.L., Extracellular signal-regulated kinase and p38 subgroups of mitogen-activated protein kinases regulate inducible nitric oxide synthase and tumor necrosis factor- $\alpha$ gene expression in endotoxin-stimulated primary glial cultures. J. Neurosci. 18: 1633-1641, 1998.

42. Haddad J.J. and Land S.C., Redox/ROS regulation of lipopolysaccharide- induced mitogen-activated protein kinase (MAPK) activation and MAPK- mediated TNF- $\alpha$ biosynthesis. Br. J. Pharmacol. 135: 520-536, 2002.

43. Li Y., Liu L., Barger S.W., Mrak R.E. and Griffin W.S., Vitamin E suppression of microglial activation is neuroprotective. J. Neurosci. Res. 66: 163-170, 2001.

44. Egger T., Hammer A., Wintersperger A., Goti D., Malle E. and Sattler W., Modulation of microglial superoxide production by alpha-tocopherol in vitro: attenuation of p67(phox) translocation by a protein phosphatase-dependent pathway. J. Neurochem. 79: 1169-1182, 2001.

45. Li Y., Liu L., Barger S.W., Mrak R.E. and Griffin W.S., Vitamin E suppression of microglial activation is neuroprotective. J. Neurosci. Res. 66: 163-170, 2001.

46. Nicholas R.S., Compston A. and Brown D.R., Inhibition of tumour necrosis factor- $\alpha(\mathrm{TNF} \alpha)$-induced NF- $\kappa \mathrm{B}$ p52 converts the metabolic effects of microglial-derived TNF $\alpha$ on mouse cerebellar neurons to neurotoxicity. J. Neurochem. 76: 1431-1438, 2001.

47. Petrova T.V., Akama K.T. and Van Eldik L.J., Cyclopentenone prostaglandins suppress activation of microglia: down-regulation of inducible nitric-oxide synthase by 15 deoxy- $\Delta^{12,14-}$ prostaglandin $\mathbf{J}_{2}$. Proc. Natl. Acad. Sci. USA 96: 4668-4673, 1999.

48. Shen Y., Shen H.M., Shi C.Y. and Ong C.N., Benzene metabolites enhance reactive oxygen species generation in HL60 human leukemia cells. Hum. Exp. Toxicol. 15: 422427, 1996.

49. Winn L.M., Homologous recombination initiated by benzene metabolites: a potential role of oxidative stress. Toxicol. Sci. 72: 143-149, 2003. 